\title{
Evaluation of inheritance pattern for leaf rust resistance genes and heritability estimates for agronomic traits in $\mathbf{F}_{2}$ progenies of bread wheat genotypes
}

\author{
Abdul Wahid Baloch ${ }^{1}$, Munaiza Baloch ${ }^{*}$, Danish Riaz Sheikh², \\ Muhammad Azeem Asad ${ }^{3}$, Gul Muhammad Baloch ${ }^{1}$, Naila Gandahi ${ }^{1}$, \\ Abdul Majeed Baloch ${ }^{4}$, Irfan Ahmed Baloch ${ }^{4}$ and Muharam Ali ${ }^{5}$ \\ 1. Department of Plant Breeding \& Genetics, Sindh Agriculture University, Tandojam, Pakistan \\ 2. Southern Wheat Research Station, Tandojam, Pakistan \\ 3. Nuclear Institute of Agriculture, Tandojam, Pakistan \\ 4. College of Horticulture, Northeast Agriculture University, Harbin, China \\ 5. Department of Biotechnology, Sindh Agriculture University, Tandojam, Pakistan \\ *Corresponding author's email: balochbreeders@ yahoo.com \\ Citation \\ Abdul Wahid Baloch, Munaiza Baloch, Danish Riaz Sheikh, Muhammad Azeem Asad, Gul Muhammad Baloch, \\ Naila Gandahi, Abdul Majeed Baloch, Irfan Ahmed Baloch and Muharam Ali. Evaluation of inheritance pattern for \\ leaf rust resistance genes and heritability estimates for agronomic traits in $\mathrm{F}_{2}$ progenies of bread Wheat genotypes. \\ Pure and Applied Biology. Vol. 5, Issue 2, 2016, pp240-246. http://dx.doi.org/10.19045/bspab.2016.50031
}

Received: $22 / 01 / 2016$

Revised: $10 / 02 / 2016$

Accepted: 18/02/2016

Online First: 04/03/2016

\section{Abstract}

The current experiment was conducted at experimental farm of Nuclear Institute of Agriculture, Tandojam, during the growing season of 2013-14, which comprised of seven wheat genotypes including four leaf rust resistant (Sunco, Vasco, SD-222 and SD-333) and three susceptible (TD1, ICARDA and SD-888). These wheat genotypes were used to develop four $\mathrm{F}_{2}$ cross combinations (TD- $1 \times$ Vasco, ICARDA $\times$ SD-222, TD- $1 \times$ Sunco and SD-888 $\times$ SD-333) for the estimation of heritability and genetic pattern of resistance genes. The observations were recorded on gain yield associated traits to evaluate genetic potential of the $F_{2}$ populations. The analysis of variance revealed significant differences $(\mathrm{P} \leq 0.05)$ among the genotypes for all the studied traits which suggested that the breeding material is worth for selection of desirable plants from subsequent segregating generations. With regards to heritability percentage in broad sense, the $\mathrm{F}_{2}$ progeny TD-1 $\times$ Sunco expressed high heritability for days to $75 \%$ heading $\left(\mathrm{h}^{2}=60.80 \%\right.$, $\mathrm{GA}=1.82)$, days to $75 \%$ maturity $\left(\mathrm{h}^{2}=71.50 \%, \mathrm{GA}=2.40\right)$ and tillers plant ${ }^{-1}\left(\mathrm{~h}^{2}=32.72 \%, \mathrm{GA}=\right.$ 12.44). Similarly, the $F_{2}$ progeny TD- $1 \times$ Vasco showed high heritability $\left(\mathrm{h}^{2}=88.89 \%\right.$, GA= 8.07) for plant height; SD-888 $\times$ SD-333 revealed high heritability $\left(h^{2}=92.33 \%, G A=29.83\right)$ for biological yield plant ${ }^{-1}$; ICARDA $\times$ SD-222 expressed high heritability $\left(h^{2}=44.61 \%, G A=12.77\right)$ for harvest index. The present findings suggest that most of the yield associated traits have been successfully transmitted. The information generated will be helpful for better understanding and selection of desirable material especially in early generations. Furthermore, phenotypic data expressed 3:1 ratio in $\mathrm{F}_{2}$ populations of four crosses which indicated that both ( $L r 24$ and $\left.L r 32\right)$ 
are single dominant genes, thus specifying the usefulness of these genes for the breeders to incorporate in mega wheat varieties susceptible to leaf rust and to save guard the future harvest.

Key words: Inheritance pattern; heritability; $F_{2}$ population; Bread wheat

\section{Introduction}

In Pakistan, wheat is being used as the staple diet and is grown on the largest acreages in almost every part of the country. Talking about area under wheat cultivation has declined to 9180 thousand hectares in 201415 from previous year's area of 9199 thousand hectares that displays a reduction of 0.2 percent. The wheat production stood at 25.478 million tonnes during 2014-15, demonstrating a decrease of 1.9 percent over the preceding year's production (25.979 million tonnes). The decline in production was associated with extended winter season and exceptional rains during the months of April and May which caused damages to grain at harvesting time [1].

The success of any breeding strategy rely on the preservation, creation and utilization of genetic diversity. Higher the genetic diversity in crop germplasm, higher the chances of getting sustainable progress in genetic improvement of crop plants against variety of stresses [2]. Estimation of heritability and genetic advance offers the knowledge about degree of transmission of trait in subsequent generations and selection response. Heritability is the component of phenotype which is being determined by genetic factors [3]. Heritability and genetic advance values help in making selection more efficient and envisaging the selection response. Therefore, trait selection based on high heritability makes the progress easier. For an effective selection, environmental variability must be less in respect to genetic differences [4]. The current research work was planned to estimate variability and genetic parameters for grain yield contributing characters in $\mathrm{F}_{2}$ populations of bread wheat and also to know the inheritance pattern of leaf rust resistance genes.

\section{Materials and methods}

The current investigation was done at the experimental area of Nuclear Institute of Agriculture (NIA), Tandojam during the wheat growing season of 2013-14. The experiment comprised of seven wheat genotypes including four leaf rust resistant (Sunco, Vasco, SD-222 and SD-333) genotypes carrying $L r-24$ and $L r$-32 genes and three rust susceptible (TD-1, ICARDA and SD-888) genotypes. After hybridization, four $\mathrm{F}_{2}$ progenies $(\mathrm{TD}-1 \times \mathrm{Vasco}$, ICARDA $\times$ SD-222, TD- $1 \times$ Sunco and SD-888 $\times$ SD333 ) were produced and these $F_{2}$ progenies were evaluated for inheritance pattern for leaf rust resistance genes. The observations were recorded on gain yield associated traits to evaluate genetic potential of the $F_{2}$ populations. The seed of rust spreader (Morocco) and rust inoculum of leaf rust were obtained from head of Plant Breeding and Genetics Division, NIA, Tandojam. The seeds of each parent and their respective $\mathrm{F}_{2}$ crosses were planted in 4 rows of 2 meter in length with plant to plant distance of 15 centimeter and row to row distance of 30 centimeter in randomized complete block design with four replications. After every 8 experimental lines, a spreader row (Morocco) was planted. The recommended dose of fertilizers and irrigations were applied accordingly. The entire data was statistically analyzed using analysis of variance method as suggested by Gomez and Gomez [5] and the means were compared by Duncan's multiple range test by Statistix v. 8.1 computer package. The heritability of different traits was calculated according to Falconer [6].

\section{Results and discussion}

The pooled analysis of variance for all the genotypes including seven parents and their four $F_{2}$ progenies revealed that both the 
parents and segregating populations differed significantly $(\mathrm{P} \leq 0.01)$ for all the traits under study, showing the existence of abundant genetic variability among the genotypes (Table 1). The results of each traits is discussed in following paragraphs.

Table 1. Mean squares for various morphological traits of four $\mathrm{F}_{2}$ populations and parental lines of wheat.

\begin{tabular}{|l|c|c|c|c|c|c|c|}
\hline \multirow{2}{*}{$\begin{array}{l}\text { Source of } \\
\text { variation }\end{array}$} & \multirow{2}{*}{$\begin{array}{l}\text { Degree of } \\
\text { freedom }\end{array}$} & $\begin{array}{l}\text { Days to } \\
\text { heading }\end{array}$ & $\begin{array}{l}\text { Days to } \\
\text { maturity }\end{array}$ & $\begin{array}{l}\text { Plant } \\
\text { height }\end{array}$ & $\begin{array}{l}\text { Tillers } \\
\text { plant }^{1}\end{array}$ & $\begin{array}{l}\text { Grain } \\
\text { yield } \\
\text { plant }\end{array}$ & $\begin{array}{l}\text { Harvest } \\
\text { index \% }\end{array}$ \\
\hline Replications & 3 & 6.57 & 2.45 & 5.92 & 9.22 & 3.16 & 0.40 \\
\hline Genotypes & 10 & $235.96^{* *}$ & $176.47^{* *}$ & $540.22^{* *}$ & $163.69^{* *}$ & $56.15^{* *}$ & $83.61^{* *}$ \\
\hline Errors & 30 & 2.83 & 0.83 & 13.14 & 5.07 & 1.67 & 6.22 \\
\hline
\end{tabular}

** = Significant at $1 \%$ probability level

\section{Days to $75 \%$ heading}

The mean performance for days to heading is given in (Table 2). Mean performance of four $F_{2}$ progenies showed that days to heading ranged from 69.00 to 96.00 days. The $\mathrm{F}_{2}$ progeny ICARDA $\times \mathrm{SD}-222$ took maximum (96.00 days) days to heading and the minimum days to heading (69.00 days) were taken by SD- $888 \times$ SD-333, indicating that $\mathrm{F}_{2}$ progeny $\mathrm{SD}-888 \times \mathrm{SD}-333$ could be utilized for the development of early maturity wheat varieties. It has been reported that higher the heritability, more effective would be the selection, whereas the high estimates are attributed to fixable component of genetic variation. The high heritability associated with low genetic advance is probably due to non-additive gene (dominance and epistasis) effects [7]. The broad sense heritability and genetic advance for days to heading was ranged from 13.74 to $76.22 \%$ and 0.63 to 5.36 , respectively. The high heritability $\left(\mathrm{h}^{2}=\right.$ $76.22 \%$ ) coupled with low genetic advance $(\mathrm{GA}=2.23)$ was found in cross combination TD-1 x Sunco. This trait can easily be fixed in the genotypes by selection in early generations.

\section{Days to $\mathbf{7 5 \%}$ maturity}

The mean performance for days to maturity (Table 2) revealed that maximum days to maturity were taken by parental line SD-333 (139.00 days) and SD-888 took minimum days to maturity (122.00 days). While, TD-1 $\times$ Sunco took maximum days to maturity (132.00 days) and the minimum days to maturity were recorded in $\mathrm{TD}-1 \times \mathrm{Vasco}$ (123.00 days). Early maturing cultivars are required to escape and combat with many abiotic and biotic stresses and also to vacate the field in time to grow other crops at proper time. These genotypes (SD-888 and TD-1 $\times$ Vasco) may be considered to develop early maturing wheat cultivars. The heritability of a character describes the extent to which it is transmitted from one generation to the next. TD-1 $\times$ Sunco expressed high heritability $\left(\mathrm{h}^{2}=71.50 \%\right)$ but coupled with low genetic advance $(\mathrm{GA}=2.40)$. It indicated that early maturity is caused by the additive effect of genes. This trait could be fixed by selecting the genotypes with less number of days to mature.

\section{Plant height (cm)}

The mean performance (Table 2) for plant height showed that the cross combination ICARDA $\times$ SD-222 grew taller plants of $106.00 \mathrm{~cm}$ and the short stature plants of $80.18 \mathrm{~cm}$ were observed in TD- $1 \times$ Sunco. It is well known fact that dwarf varieties are quiet useful in wheat since these genotypes show better response for nitrogen uptake and also exhibit greater resistance against lodging. So, the cross combination TD- $1 \times$ Sunco could particularly be utilized to 
develop short stature wheat varieties. All cross combinations showed high heritability percentage; however, among all cross combinations, TD-1 $\times$ Vasco showed the highest heritability $\left(\mathrm{h}^{2}=88.89 \%\right)$ coupled with low genetic advance $(\mathrm{GA}=8.07)$. These results are in agreement with those of Asif [8] and Hussain [9].

\section{Tillers plant ${ }^{-1}$}

The maximum number of tillers plant $^{-1}$ (21.17) was recorded in TD- $1 \times$ Sunco and minimum tillers plant $^{-1}$ (11.00) were observed in SD-888 $\times$ SD-333. Number of tillers plant ${ }^{-1}$ is controlled by the genetic factors and expressed by transgression to their hybrids [10]. So, selection for number of tillers plant ${ }^{-1}$ would be useful for wheat breeders to improve wheat grain yield plant 1. High heritability $\left(h^{2}=63.66 \%\right)$ was shown by the $\mathrm{F}_{2}$ progeny SD-888 x SD-333 coupled with high genetic advance $(\mathrm{GA}=24.80)$. Ansari [11] reported high heritability coupled with high genetic advance in bread wheat hybrids for tillers plant ${ }^{-1}$. He suggested that the selection scope for the tillers plant ${ }^{-1}$ would be more effective for the improvement of trait and for yield as well. It could be suggested that selection of tillers plant $^{-1}$ would be more effective for improvement of grain yield in wheat crop.

Table 2. Means performance of seven parental lines and their four $F_{2}$ populations of wheat for various traits

\begin{tabular}{|l|l|l|l|l|l|l|}
\hline $\begin{array}{l}\text { Parents and } \\
\text { F progenies }\end{array}$ & $\begin{array}{l}\text { Days to 75\% } \\
\text { heading }\end{array}$ & $\begin{array}{l}\text { Days to 75\% } \\
\text { maturity }\end{array}$ & $\begin{array}{l}\text { Tillers } \\
\text { plant }^{-1}\end{array}$ & $\begin{array}{l}\text { Plant height } \\
(\mathbf{c m})\end{array}$ & $\begin{array}{l}\text { Biological } \\
\text { yield plant } \\
\text { (-1 }\end{array}$ & $\begin{array}{l}\text { Harvest } \\
\text { index (\%) }\end{array}$ \\
\hline TD-1 & $85.00 \mathrm{~d}$ & $127 . .00 \mathrm{c}$ & $19.11 \mathrm{~b}$ & $68 \mathrm{~d}$ & $66.12 \mathrm{a}$ & $17.92 \mathrm{~b}$ \\
\hline Vasco & $89.00 \mathrm{bc}$ & $138.00 \mathrm{a}$ & $21.00 \mathrm{~b}$ & $80 \mathrm{c}$ & $61.63 \mathrm{ab}$ & $15.15 \mathrm{bc}$ \\
\hline Sunco & $97.00 \mathrm{a}$ & $138.00 \mathrm{a}$ & $25.33 \mathrm{a}$ & $80 \mathrm{c}$ & $64.82 \mathrm{a}$ & $11.91 \mathrm{~cd}$ \\
\hline ICARDA & $85.00 \mathrm{~d}$ & $138.00 \mathrm{a}$ & $21.25 \mathrm{~b}$ & $97 \mathrm{~b}$ & $55.11 \mathrm{abc}$ & $14.26 \mathrm{bcd}$ \\
\hline SD-222 & $90.00 \mathrm{~b}$ & $131.00 \mathrm{~b}$ & $14.06 \mathrm{c}$ & $84 \mathrm{c}$ & $40.57 \mathrm{~d}$ & $11.04 \mathrm{~d}$ \\
\hline SD-888 & $85.00 \mathrm{~d}$ & $122.00 \mathrm{e}$ & $7.00 \mathrm{~d}$ & $64 \mathrm{~d}$ & $27.31 \mathrm{e}$ & $17.87 \mathrm{~b}$ \\
\hline SD-333 & $86.00 \mathrm{a}$ & $139.00 \mathrm{a}$ & $5.00 \mathrm{~d}$ & $79 \mathrm{c}$ & $23.95 \mathrm{e}$ & $17.77 \mathrm{~b}$ \\
\hline $\begin{array}{l}\text { TD-1 } \\
\text { Vasco }\end{array}$ & $87.00 \mathrm{~cd}$ & $123.00 \mathrm{e}$ & $19.66 \mathrm{~b}$ & $85 \mathrm{c}$ & $59.78 \mathrm{ab}$ & $28.51 \mathrm{a}$ \\
\hline $\begin{array}{l}\text { ICARDA } \\
\text { SD-222 }\end{array}$ & $96.00 \mathrm{a}$ & $126.00 \mathrm{c}$ & $14.58 \mathrm{c}$ & $106.00 \mathrm{a}$ & $46.00 \mathrm{~cd}$ & $16.49 \mathrm{~b}$ \\
\hline $\begin{array}{l}\text { TD-1 } \\
\text { Sunco }\end{array}$ & $79.00 \mathrm{~b}$ & $132.00 \mathrm{~b}$ & $21.00 \mathrm{~b}$ & $80 \mathrm{c}$ & $59.71 \mathrm{ab}$ & $17.69 \mathrm{~b}$ \\
\hline $\begin{array}{l}\text { SD-888 } \\
\text { SD-333 }\end{array}$ & $69.00 \mathrm{f}$ & $124.00 \mathrm{~d}$ & $11.00 \mathrm{c}$ & $83 \mathrm{c}$ & $51.77 \mathrm{bc}$ & $15.61 \mathrm{bc}$ \\
\hline LSD $5 \%)$ & 2.431 & 1.31 & 3.253 & 5.236 & 9.785 & 3.603 \\
\hline
\end{tabular}

\section{Biological yield plant ${ }^{-1}$}

Regarding mean performance (Table 3) of biological yield plant ${ }^{-1}$, the $\mathrm{F}_{2}$ progeny TD-1 $\times$ Vasco yielded higher biological yield plant $^{-1}(59.78 \mathrm{~g})$ than all the parental and $\mathrm{F}_{2}$ progenies except the parental line TD-1 which produced maximum biological yield plant $^{-1}(66.12 \mathrm{~g})$. For the trait biological yield plant $^{-1}$, low, moderate and high heritability was observed in different $\mathrm{F}_{2}$ progenies, referring genetic existence of variability in $F_{2}$ populations and desirable level of biological yield plant $^{-1}$ may be effectively selected from these crosses. High heritability $\left(h^{2}=92.33 \%\right)$ found in SD- $888 \times$ SD-333 whereas, high genetic advance for biological yield $(\mathrm{GA}=29.83)$ was also observed in the same $F_{2}$ progeny. Jadoon 
[12] reported high heritability and high genetic advance for biological yield.

Table 3. Genetic variance $\left(\sigma^{2} \mathbf{g}\right)$, phenotypic variance $\left(\sigma^{2} p\right)$, heritability percentage in broad sense ( $h^{2}$ b.s) and genetic advance (GA) for various traits in $4 F_{2}$ generations of bread wheat

\begin{tabular}{|c|c|c|c|c|c|}
\hline Characters & $F_{2}$ progenies & $\begin{array}{c}\text { Genetic } \\
\text { variance }\left(\sigma^{2} g\right)\end{array}$ & $\begin{array}{c}\text { Phenotypic } \\
\text { variance }\left(\sigma^{2} \mathbf{p}\right)\end{array}$ & $\begin{array}{c}\text { Heritability } \\
\left(h^{2} \%\right) \text { broad } \\
\text { sense }\end{array}$ & $\begin{array}{l}\text { Genetic } \\
\text { advance } \\
\text { (GA) }\end{array}$ \\
\hline \multirow{4}{*}{$\begin{array}{c}\text { Days to } \\
75 \% \\
\text { heading }\end{array}$} & TD-1 $\times$ Vasco & 0.43 & 2.25 & 18.83 & 0.63 \\
\hline & $\begin{array}{c}\text { ICARDA } \times \text { SD- } \\
222\end{array}$ & 0.80 & 1.31 & 60.80 & 1.82 \\
\hline & TD-1 $\times$ Sunco & 0.88 & 1.15 & 76.22 & 2.23 \\
\hline & $\begin{array}{c}\text { SD- } 888 \times \text { SD- } \\
333\end{array}$ & 0.18 & 1.31 & 13.74 & 5.36 \\
\hline \multirow{4}{*}{$\begin{array}{c}\text { Days to } \\
75 \% \\
\text { maturity }\end{array}$} & TD- $1 \times$ Vasco & 1.11 & 1.65 & 67.27 & 2.30 \\
\hline & $\begin{array}{l}\text { ICARDA } \times \text { SD- } \\
222\end{array}$ & 0.43 & 1.03 & 44.83 & 1.04 \\
\hline & TD-1 $\times$ Sunco & 1.11 & 1.55 & 71.50 & 2.40 \\
\hline & $\begin{array}{c}\text { SD- } 888 \times \text { SD- } \\
333 \\
\end{array}$ & 0.11 & 1.59 & 6.91 & 1.80 \\
\hline \multirow{4}{*}{ Plant height } & TD- $1 \times$ Vasco & 1.81 & 2.03 & 88.89 & 8.07 \\
\hline & $\begin{array}{l}\text { ICARDA } \times \text { SD- } \\
222 \\
\end{array}$ & 2.06 & 2.79 & 69.21 & 6.80 \\
\hline & TD-1 $\times$ Sunco & 1.57 & 2.38 & 65.61 & 6.61 \\
\hline & $\begin{array}{c}\text { SD- } 888 \times \text { SD- } \\
333 \\
\end{array}$ & 1.85 & 2.09 & 88.29 & 8.34 \\
\hline \multirow{4}{*}{$\begin{array}{l}\text { Tillers } \\
\text { plant }^{-1}\end{array}$} & TD- $1 \times$ Vasco & 1.89 & 5.94 & 31.84 & 1.83 \\
\hline & $\begin{array}{l}\text { ICARDA } \times \text { SD- } \\
222\end{array}$ & 0.71 & 2.55 & 27.89 & 9.82 \\
\hline & TD-1 $\times$ Sunco & 0.96 & 2.94 & 32.72 & 12.44 \\
\hline & $\begin{array}{c}\text { SD- } 888 \times \text { SD- } \\
333\end{array}$ & 0.78 & 1.22 & 63.66 & 24.80 \\
\hline \multirow{4}{*}{$\begin{array}{l}\text { Biological } \\
\text { yield plant }\end{array}$} & TD-1 $\times$ Vasco & 2.07 & 13.21 & 15.66 & 7.61 \\
\hline & $\begin{array}{c}\text { ICARDA } \times \text { SD- } \\
222\end{array}$ & 0.68 & 11.96 & 5.72 & 3.24 \\
\hline & TD-1 $\times$ Sunco & 3.92 & 12.16 & 32.22 & 17.88 \\
\hline & $\begin{array}{c}\text { SD- } 888 \times \text { SD- } \\
333\end{array}$ & 4.12 & 4.46 & 92.33 & 29.83 \\
\hline \multirow{4}{*}{$\begin{array}{c}\text { Harvest } \\
\text { index }\end{array}$} & TD-1 $\times$ Vasco & 1.00 & 2.80 & 35.47 & 9.74 \\
\hline & $\begin{array}{l}\text { ICARDA } \times \text { SD- } \\
222 \\
\end{array}$ & 0.71 & 1.58 & 44.61 & 12.77 \\
\hline & TD-1 $\times$ Sunco & 0.65 & 2.36 & 27.42 & 9.62 \\
\hline & $\begin{array}{c}\text { SD- } 888 \times \text { SD- } \\
333 \\
\end{array}$ & 0.75 & 2.70 & 27.66 & 10.85 \\
\hline
\end{tabular}




\section{Introgression of resistance genes}

The result of scoring of parental lines and their $F_{2}$ progenies indicated that all resistant parents exhibited resistance to the prevailing race of rust, whereas susceptible parents revealed susceptibility in the field. In each $\mathrm{F}_{2}$ progeny of TD- $1 \times$ Vasco, ICARDA $\times$ SD-222, TD-1 $\times$ Sunco, SD-888 $\times$ SD-333 out of 20 plants $14,14,16$ and 13 were resistant plants; whereas, 6, 6, 4, and 7 were observed susceptible, respectively (Table 4). The 3: 1 ratio based on reaction pattern in the field is an indicative of the involvement of single dominant gene for resistance to leaf rust. These resistant genes could be proved valuable for the development of new resistant cultivars in wheat breeding program to face the new challenges of rust threat in Southeast Asia, especially in Sindh province.

Table 4. Reaction pattern of parental lines and four $F_{2}$ populations in the field

\begin{tabular}{|c|c|c|c|c|}
\hline \multirow{2}{*}{ F } & \multirow{2}{*}{$\begin{array}{c}\text { Expected } \\
\text { segregation }\end{array}$} & \multicolumn{3}{|c|}{ Odult plant stage } \\
\cline { 3 - 5 } & & \multicolumn{3}{|c|}{ Observed segregation } \\
\cline { 3 - 5 } & Resistant & 20 & 0 & $\mathbf{x}^{\mathbf{2}}$ \\
\hline SD-333 & Resistant & 20 & 0 & 0 \\
\hline Vasco & Resistant & 20 & 0 & 0 \\
\hline Sunco & Resistant & 20 & 0 & 0 \\
\hline SD-222 & Susceptible & 0 & 20 & 0 \\
\hline TD-1 & Susceptible & 0 & 20 & 0 \\
\hline SD-888 & Susceptible & 0 & 20 & 0 \\
\hline ICARDA & 3.1 & 14 & 6 & 0.266 \\
\hline TD-1 $\times$ Vasco & 3.1 & 14 & 6 & 0.266 \\
\hline ICARDA $\times$ SD-222 & 3.1 & 16 & 4 & 0.266 \\
\hline TD1 $\times$ Sunco & 3.1 & 13 & 7 & 1.06 \\
\hline SD-888 $\times$ SD-333 & & & 0 \\
\hline
\end{tabular}

\section{Authors' contributions}

Conceived and designed the experiments: AW Baloch, GM Baloch \& MA Asad. Performed the experiments: DR Sheikh, N Gandahi \& IA Baloch. Analyzed the data: M Baloch \& AM Baloch. Contributed reagents/materials/analyses tools: MA Asad \& M Ali. Wrote the paper: AW Bloch \& M Baloch.

\section{References}

1. Anonymous (2014). Pakistan Economic Survey 2013-14. Ministry of Finance, Government of Pakistan, Islamabad. p.19-21.
2. Ijaz F, Khaliq I \& Shahzad MT (2015). Estimation of heritability for some yield contributing traits in $\mathrm{F}_{2}$ populations of bread wheat (Triticum aestivum L.). $J$ Agri Res 53(2): 157-164.

3. Khan AS, Salim I \& Ali Z (2003). Heritability of various morphological traits in wheat. Inter J Agri Bot 5(2): 131140.

4. Khaliq I, Noorka IR \& Khaliq R (2009). Estimation of heritability and genetic advance for quantitative characters in spring wheat. Int J Agri Appl Sci (1):7678. 
5. Gomez KA \& Gomez AA (1984). Statistical procedures for agricultural research. John Wiley \& Sons Inc. 2nd (ed.) New York U.S.A.

6. Falconer DS (1977). Introduction to Quantitative Genetics. Richard Clay Ltd. Bungay Sufolk, Great Britain pp.129185.

7. Larik AS, Kakar AA, Naz MA \& Shaikh MA (1999). Estimation of genetic parameters in bread wheat (Triticum aestivum L.) crosses. Sarhad J Agri 15(1): 203-204.

8. Asif M, Mujahid Y, Kisana NS, Mustafa SZ \& Ahmad I (2004). Heritability, genetic variability and path coefficient of traits in spring wheat. Sarhad J Agri 20(1):87-91.

9. Hussain F, Rafiq M, Iqbal Z, Iqbal J \& Chowdhry MA (2013). Estimates of heritability and genetic advance for grain yield and its components in different segregating populations of wheat. J Agri Res 51(4)-349-360.

10. Memon SM, Qureshi D, Ansari BA \& Sial MA (2007). Genetic heritability for grain yield and its related characters in spring wheat (Triticum aestivum L.). Pak J Bot 89(5):1503-1509.

11. Ansari BA, Soomro ZA, Ansari KA \& Sethar H (2003). Heritability of grain yield and its components in $F_{5}$ population of spring wheat adapted in Sindh province of Pakistan. Pak J Agri Agri Engg Vet Sci 19(1): 14-21.

12. Jadoon SA, Mohammad F, Ullah H \& Khalil IH (2012). Gene action for pre and postharvest traits in $\mathrm{F}_{2}$ wheat populations, $Q \quad$ Science. http://dx.doi.org/10.5339. 